\title{
CIRCULATING FREE NUCLEIC ACID EXPRESSION IN SPINAL CORD INJURY
}

\author{
Sara Mohammed Mohammed Salah ${ }^{1}$, Marwa Matboli ${ }^{1}$, Hanaa El- Tayeb Nasser ${ }^{1}$ \\ Ebraheem Abd El-Mohsen Abd El-Naeem ${ }^{2}$, Ayman El-sayed Shafei ${ }^{3}$, and \\ Mohamed Farid EL -Asmer ${ }^{1}$
}

\begin{abstract}
${ }^{1}$ Medical Biochemistry and Molecular biology Department,

${ }^{2}$ Neurosurgery Department, Faculty of Medicine, Ain Shams University, and ${ }^{3}$ Armed Forces College of Medicine, Cairo, Egypt Corresponding :
\end{abstract}

Sara Mohamed Mohamed Salah Mobile: 01006792969.

\section{E mail:}

sarashamlol@yahoo.com

Received: 7/10/2019

Accepted: 6/11/201

\begin{abstract}
Background: Spinal Cord Injury (SCI) remains one of the most devastating and difficult to manage medical pathologies despite the tremendous progress in neuroscience and neurosurgery. These injuries bear substantial personal and economic burden. SCI is the underlying cause for 1 of every 40 patients admitted to a major trauma centre in EGYPT. The prevalence rate of SCD was 63/100,000 for the total population. Traumatic spinal cord injury had a prevalence of 18/100,000, while non-traumatic SCI was found in 45/100,000
\end{abstract}

Aim of the work: we aimed to explore the role of circulating TP53INP2 mRNA in spinal cord injury pathogenesis.

Patients and methods: We used bioinformatics analysis to identify autophagy related pathway and spinal cord -specific mRNA, real-time reverse-transcription $P C R$ for determining the relative expression of TP53INP2 mRNA in sera and tissue samples. We assessed the serum expression of the chosen mRNA in 23 individuals with acute spinal cord injury, 41 individuals with chronic spinal cord injury, and 36 healthy control.

Results: Our study revealed that TP53INP2 mRNA expression was significantly increased in the serum of SCI patients compared with that of the control group.

Conclusion: The results demonstrated the significant high expression ofTP53INP2 mRNA in SCI patients, further findings arising from this study will help to guide therapeutic strategies for SCI.

Key words: SCI, Spinal cord injury, mRNA, Serum, therapeutic.

\section{INTRODUCTION:}

Spinal Cord Injury (SCI) is major devastating and difficult to manage medical pathologies despite the tremendous progress in neuroscience and neurosurgery. The National SCI Statistical Center (NSCISC) in 2018 reported more than 17,700 new cases and a total of 288,000 patients living with SCI in the USA alone ${ }^{(1)}$. However, the available tools to assess the severity of spinal cord tissue destruction and to predict recovery for SCI patient are still limited ${ }^{(2 ; 3)}$.
Efforts are underway to find alternative measures to quantify injury, assess spinal cord structure and neurophysiology, and define patients' specific factors to improve prognosis, optimize treatment, define mechanisms of action, and stratify enrollment in $\mathrm{SCI}^{(4)}$.

Biological markers of spinal cord injury that objectively stratify the severity of cord damage would greatly facilitate clinical trials of novel therapies for acute SCI. Additionally, such biomarkers may be able 
to predict spontaneous neurologic recovery over time with greater precision, sensitivity and reproducibility than the standard clinical examination, which in turn would reduce the number of patients needed to sufficiently power clinical trials ${ }^{(\mathbf{5})}$.

Liquid biopsy is becoming a very popular sample obtaining procedure, replacing the invasive sampling methods for the diagnostic protocols. The advantages of this method include the possibility to isolate cell-free nucleic acids (cfNAs) for diagnostic or screening purposes ${ }^{(6)}$.

The cfNAs are present in biological fluids. The phenomenon of ccfNA (DNA, RNA, fetal DNA, fetal RNA, mitochondrial DNA and mitochondrial RNA) ${ }^{(7)}$.

Studies are not only limited to proteincoding genes but also extends to several classes of structurally and functionally different non-coding RNAs ${ }^{(\mathbf{8 , 9})}$.

Autophagy plays an important role in the development and pathogenesis of various diseases. Many neurological disorders such Alzheimer's disease, amyotrophic lateral sclerosis, cerebral ischemia, and acute spinal cord injury (ASCI), are closely related to autophagy. However, therapeutic strategies to manipulate autophagy have not yet been fully deciphered due to the limited knowledge of the molecular mechanisms underlying autophagy in these disorders ${ }^{(\mathbf{1 0})}$.

In this study, we first identified SCI associated autophagy related gene. Then, to confirm this, we assessed whether p53 inducible nuclear protein 2 (TP53INP2) mRNA are altered in sera of SCI patients compared with healthy volunteers.

In this study our target gene was tumor protein p53 inducible nuclear protein 2 (TP53INP2) gene which promotes autophagy and is essential for proper autophagosome formation and processing ${ }^{(11)}$.

\section{MATERIAL AND METHODS}

Participates were enrolled in the pilot study after approval of the Committee of Ethics Ain Shams faculty of medicine Ethical Committee, from January 2017 till July 2018.

The participants were 64 patients' gender and age matched with 36 normal healthy volunteers. All patients were diagnosed with spinal cord injuries according to the American Spinal cord Injury Association Guidelines, 23 patients with acute (from 2 hrs $-<2$ days after injury)spinal cord injury and 41 with chronic( $\geq 2$ weeks after injury) spinal cord injury. They were recruited from the Neurosurgery Department at Ain Shams University hospitals. Informed consent was taken from all participants.

Patients with history of any Psychiatric, other neurological, autoimmune and neoplastic disorder or with any comorbidity were excluded from the study.

Serum was obtained by centrifugation $3,000 \mathrm{rpm}$ for $10 \mathrm{~min}$, then aliquoted and stored at $-80^{\circ} \mathrm{C}$ until further processing.

\section{Bioinformatics-based selection of the} RNA-based biomarker:

We have selectedTP53INP2mRNA gene which is highly correlated to autophagy and is essential for proper auto-phagosome formation and processing. To confirm the expression of TP53INP2 gene (TP53INP2 $m R N A$ ) in spinal cord injury cases; we searched Gene Atlas database (available at https://www.ebi.ac.uk/gxa/home) as shown in figure (1) and we verified the expression of TP53INP2 IN spinal cord by using genecards database available https://www. genecards.org/ as shown in figure (2). 


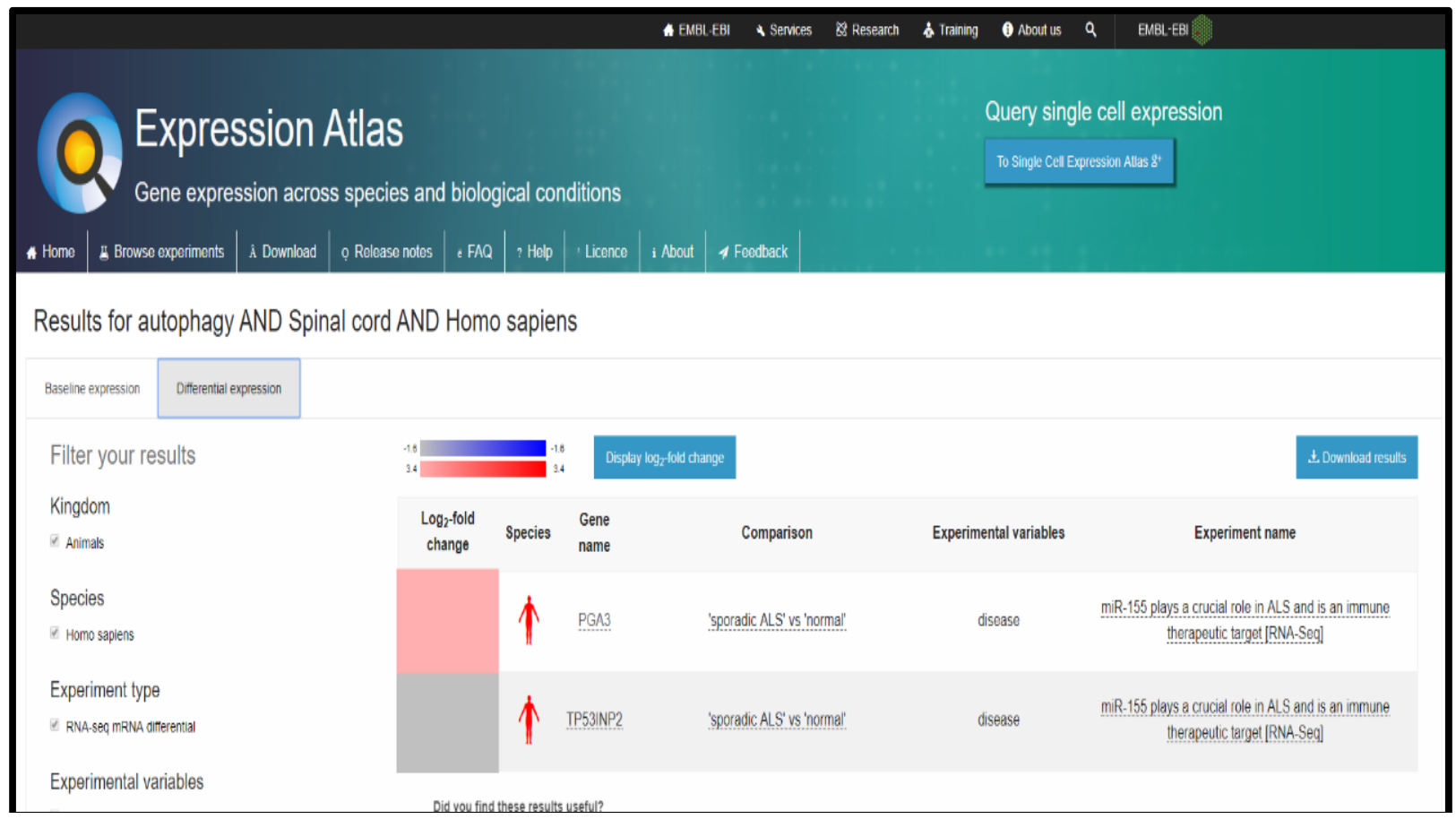

Figure 1: Print screen shows the expression of TP53INP2 mRNA in spinal cord from gene atlas database, available at https://www.ebi.ac.uk/gxa/home

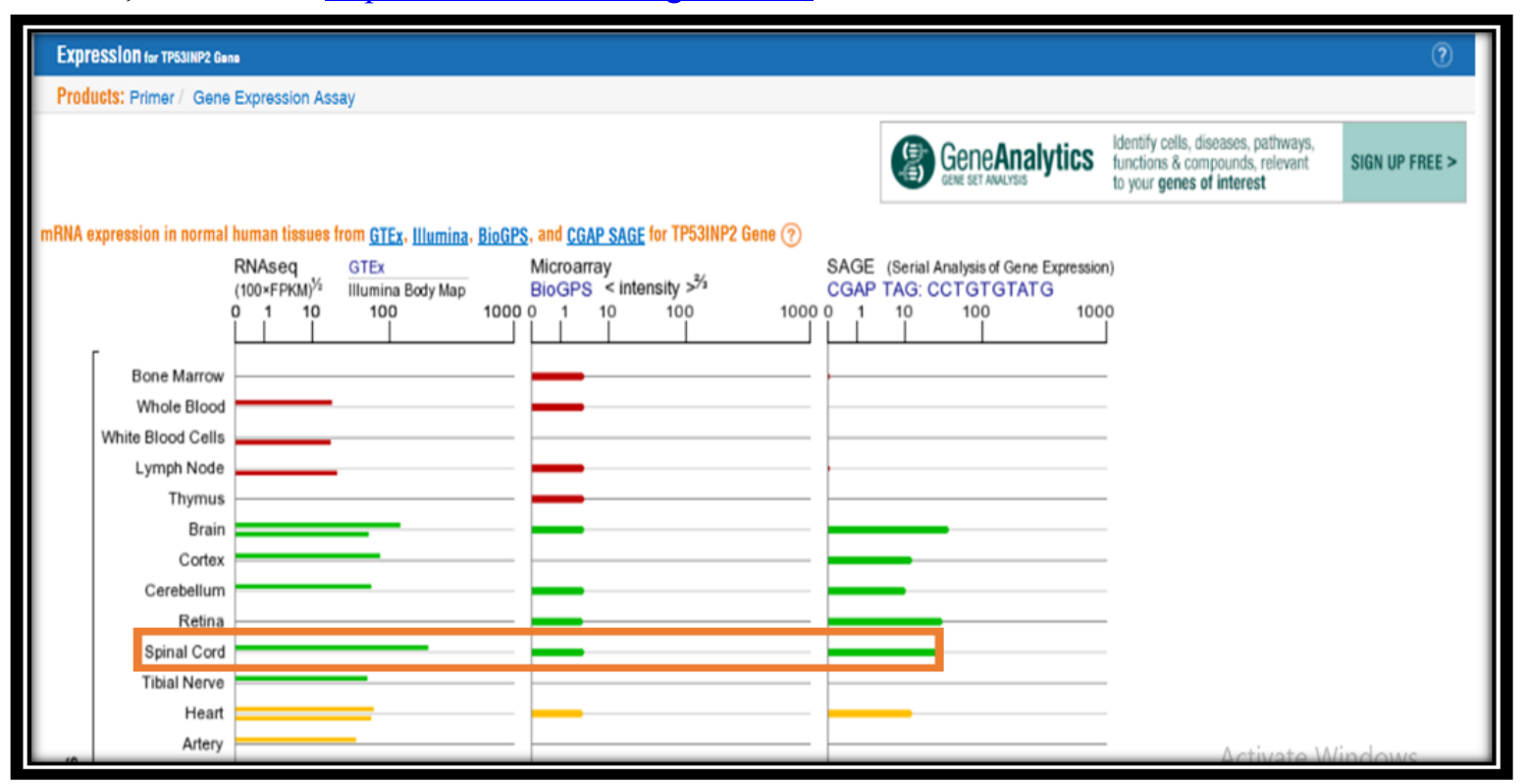

Figure 2: Snapshot shows the verification of expression of TP53INP2 gene in normal spinal cord, available at https://www.genecards.org

Validation of the chosen RNA based biomarkers in human clinical samples by $\mathrm{q}$ $\underline{\text { PCR: }}$

1. Extraction of total RNA from sera samples \& reverse transcription
Total RNA was extracted using miRNEasy RNA isolation kit (Qiagen, Hilden, Germany) according to manufacturer's instructions. Total RNA samples were dissolved in $30 \mu 1$ of nucleasefree water, quality and quantity were checked using Nano Drop spectro- 
photometer. cDNA libraries for mRNAs was prepared using miScript II RT Kit (Qiagen, Germany). 4ul 5x miScript HiFlex Buffer, 2ul 10x miScript Nucleics Mix, 1ul miScript Reverse Transcriptase Mix and RNase free water were added to 2 ug RNA extract, then incubated at $37^{\circ} \mathrm{C}$ for 60 minutes and at 95 ${ }^{\circ} \mathrm{C}$ for 5 minutes using Rotor gene Thermal cycler (Thermo Electron Waltham, MA).

2. Quantification of mRNA by Real Time$\underline{\text { PCR }}$

TP53INP2mRNA expression in sera samples of SCI and healthy control groups were quantified by qRT-PCR by using QuantiTect SYBR-Green PCR Master Mix (Roche) and 10ul 2x RT $^{2}$ SYBR Green ROX qPCR Mastermix, Sequentially, Specific primer for our gene was designed. TP53INP2 QuantiTect Primer Assay (NM_021202), PCR primer was purchased from (Qiagen, Germany MD), RNase free water and $2 \mathrm{ul}$ template cDNA to a final volume of 20ulHs_ACTB_1_SG QuantiTect Primer Assay (NM_001101) was used as housekeeping gene in equalization of raw data like the invariant control for the samples and to compare with reference sample. PCR programed for relative quantification as follows: Initial denaturation at $95^{\circ} \mathrm{C}$ for $10 \mathrm{~min}$; followed by 45 cycles at $95^{\circ} \mathrm{C}$ for $15 \mathrm{sec}$; then annealing at $55^{\circ} \mathrm{C}$ for $30 \mathrm{sec}$ and extension at $70^{\circ} \mathrm{C}$ for $30 \mathrm{~s}$.

Fold change and expression levels were calculated using $2^{-\Delta \Delta \mathrm{Ct}} \operatorname{method}^{(\mathbf{1 2})}$.

The Rotor Gene real time PCR detection system (Qiagen, Hilden, Germany) calcula- ted the threshold cycle $(\mathrm{Ct})$ value of each sample, negative if higher than $36 \mathrm{Ct}$ value. Amplification plot curve analyzed the results for Sybr Green -based PCR amplification. Melting curve was analyzed to confirm the specificities of the amplicons and $\mathrm{Tm}$ values.

\section{Statistics:}

The data was statistically presented using Statistical Package for the Social Sciences (SPSS, Chicago, IL) SPSS 20. Appropriate tests including Independent $\mathrm{t}$ test, chi-square test, and Mann Whitney test were used. The receiver operating characteristic (ROC) curve was done to characterize the predictive value of selected RNA based biomarker panel for SCI. The Spearman correlation was carried out to detect the associations between clinicpathological parameters and RNA based biomarker panel expression. Two-tailed $\mathrm{P}$ value of 0.05 or less was supposed to be statistically significant.

\section{RESULTS}

\section{Description of the study population}

No statistical significant differences were found regarding age, sex, smoking or hypertension among the three groups, only DM was significant between groups $(\mathrm{p}>0.05)$, the mean age of the groups $=$ 44.2. Details of the demographic and clinical data are shown in Table (1). 
Table 1: The Clinicopathological Factors in Different Groups Of the study.

\begin{tabular}{|c|c|c|c|c|c|}
\hline & $\begin{array}{c}\text { Acute SCI } \\
\mathrm{N}(\%)\end{array}$ & $\begin{array}{c}\text { Chronic SCI } \\
\text { N (\%) }\end{array}$ & $\begin{array}{c}\text { Healthy Control } \\
\mathrm{N}(\%)\end{array}$ & $\chi^{2(a)}$ & $P$ \\
\hline $\begin{array}{l}\text { Age } \\
\quad \geq 44.2 \\
<44.2 \\
\end{array}$ & $\begin{array}{l}\text { (10) } 43.5 \% \\
\text { (13) } 56.5 \%\end{array}$ & $\begin{array}{l}\text { (27) } 65.9 \% \\
(14) 34.1 \%\end{array}$ & $\begin{array}{l}\text { (18) } 50 \% \\
\text { (18) } 50 \%\end{array}$ & $\chi^{2}=3.5$ & $\mathrm{P}=0.17$ \\
\hline $\begin{array}{l}\text { Sex: } \\
\quad \text { Male (74) } \\
\quad \text { Female (26) }\end{array}$ & $\begin{array}{c}18(78.3 \%) \\
5(21.7 \%)\end{array}$ & $\begin{array}{l}30(73.2 \%) \\
11(26.8 \%)\end{array}$ & $\begin{array}{l}26(72.2 \%) \\
10(27.8 \%)\end{array}$ & $\chi^{2}=0.291$ & $.865 \mathrm{NS}$ \\
\hline \begin{tabular}{|l} 
Smoking: \\
Smoker (32) \\
Non-Smoker (68) \\
\end{tabular} & $\begin{array}{c}9(39.1 \%) \\
14(60.9 \%)\end{array}$ & $\begin{array}{l}14(34.1 \%) \\
27(65.9 \%) \\
\end{array}$ & $\begin{array}{c}9(25 \%) \\
27(75 \%) \\
\end{array}$ & $\chi^{2}=1.435$ & $.488 \mathrm{NS}$ \\
\hline \begin{tabular}{|l} 
Hypertension: \\
Positive (19) \\
Negative (81) \\
\end{tabular} & $\begin{array}{l}11(47.8 \%) \\
12(52.2 \%)\end{array}$ & $\begin{array}{l}11(26.8 \%) \\
30(73.2 \%)\end{array}$ & $\begin{array}{c}8(22.2 \%) \\
28(77.8 \%)\end{array}$ & $\chi^{2}=4.714$ & $.095 \mathrm{NS}$ \\
\hline \begin{tabular}{|c|} 
Diabetes Mellitus: \\
Positive (28) \\
Negative (72) \\
\end{tabular} & $\begin{array}{l}12(52.2 \%) \\
11(47.8 \%)\end{array}$ & $\begin{array}{c}8(19.5 \%) \\
33(80.5 \%)\end{array}$ & $\begin{array}{c}8(22.2 \%) \\
28(77.8 \%) \\
\end{array}$ & $\chi^{2}=8.728$ & $.013^{*}$ \\
\hline \begin{tabular}{|c|} 
ASIA \\
A \\
B \\
C \\
D \\
E \\
\end{tabular} & $\begin{array}{c}14(60.9 \%) \\
9(39.1 \%) \\
0(0 \%) \\
0(0 \%) \\
0(0 \%)\end{array}$ & $\begin{array}{c}9(22 \%) \\
7(17.1 \%) \\
4(9.8 \%) \\
17(41.5 \%) \\
4(9.8 \%)\end{array}$ & & & \\
\hline \begin{tabular}{|l} 
Area of spinal cordaffected \\
One area \\
Two areas \\
Junctional area \\
\end{tabular} & $\begin{array}{c}11(47.8 \%) \\
2(8.7 \%) \\
10(43.5 \%) \\
\end{array}$ & $\begin{array}{c}27(65.9 \%) \\
1(2.4 \%) \\
13(31.7 \%) \\
\end{array}$ & & & \\
\hline \begin{tabular}{|l} 
Motor power \\
Paraplegia \\
Quadriplegia \\
Paraparesis \\
Quadriparesis \\
Monoparesis \\
Intact \\
\end{tabular} & $\begin{array}{c}16(68.6 \%) \\
7(30.4 \%) \\
0(0 \%) \\
0(0 \%) \\
0(0 \%) \\
0(0 \%) \\
\end{array}$ & $\begin{array}{c}11(26.8 \%) \\
5(12.2 \%) \\
18(43.9 \%) \\
1(2.4 \%) \\
2(4.9 \%) \\
4(9.8 \%) \\
\end{array}$ & & & \\
\hline \begin{tabular}{|l|} 
Grading(MMT) \\
G0 \\
G1 \\
G2 \\
G3 \\
G4 \\
G5 \\
\end{tabular} & $\begin{array}{c}23(100 \%) \\
0(0 \%) \\
0(0 \%) \\
0(0 \%) \\
0(0 \%) \\
0(0 \%)\end{array}$ & $\begin{array}{c}16(39 \%) \\
3(7.3 \%) \\
2(4.9 \%) \\
8(19.5 \%) \\
8(19.5 \%) \\
4(9.8 \%)\end{array}$ & & & \\
\hline
\end{tabular}

a Chi- square test $p$ : NS; not significant $(>0.05), \quad * * p<0.01$ : is highly significant, $\quad * p \leq 0.05$ :is significant, ASIA: American Spinal cord Injury Association, MMT: Manual Muscle Testing, SCI: spinal cord injury, $\mathrm{n}=100$.

\section{Expression of the serum TP53INP2 mRNA among the study groups}

The Mean Rank relative quantity (RQ) values of TP53INP2in the Acute SCI group, the Chronic SCI group and healthy control, were51.4, 71.16, and 26.39respectively. Thus, there was a highly significant difference among the three studied groups, there was a highly significant difference between acute SCI group and chronic SCI group $(p<0.01)$ and between chronic SCI group and healthy control group $(\mathrm{p}<0.01)$, also There was a highly significant difference between acute SCI group and healthy control group $(\mathrm{p}<0.01)$ as revealed in Figure (3) and Table (2). 
Sara Mohammed Mohammed Salah, et al.,

Table 2: Expression of serum TP53INP2 mRNA among the study groups.

\begin{tabular}{|c|c|c|c|c|c|c|c|c|}
\hline & \multicolumn{6}{|c|}{ Group } & \multirow{3}{*}{$\chi^{2(a)}$} & \multirow{3}{*}{$\mathrm{p}$} \\
\hline & \multicolumn{2}{|c|}{ Acute SCI } & \multicolumn{2}{|c|}{ Chronic SCI } & \multicolumn{2}{|c|}{ Healthy Control } & & \\
\hline & Median & Mean rank & Median & Mean rank & Median & Mean rank & & \\
\hline RQ of TP53INP2 mRNA & 14.123 & 51.4 & 82.13 & 71.16 , & 1.12 & 26.39 & 45 & $.000 * *$ \\
\hline
\end{tabular}

a: Kruskal Wallis test, SCI: Spinal Cord Injury, mRNA: messenger ribonucleic acid, RQ: Relative quantification, ${ }^{* *} \mathrm{p}<0.01$ : Highly Significant difference.

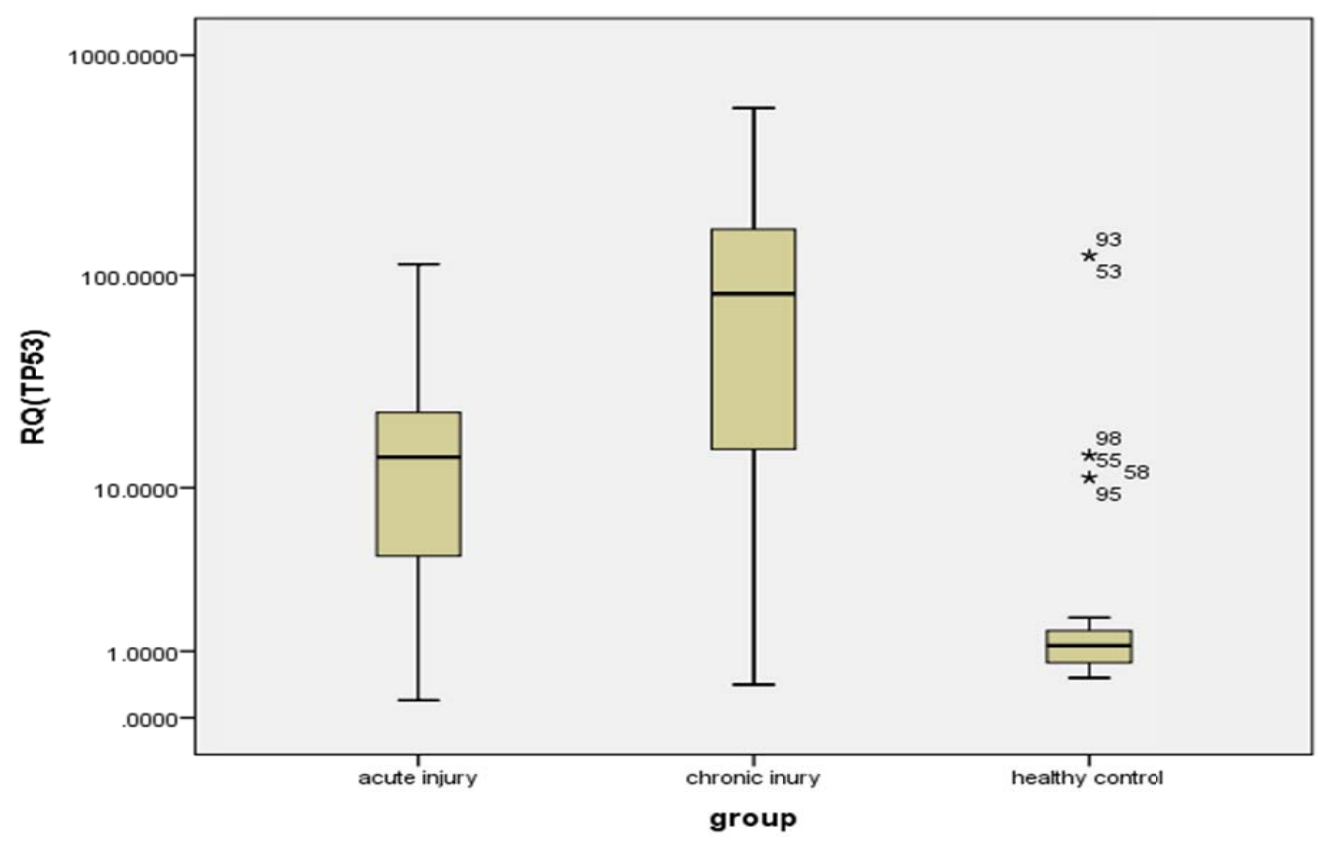

Figure 3: BOXPLOT of SerumTP53INP2determined by qRT-PCR among the Acute SCI, Chronic $\mathrm{SCI}$, and healthy control groups. The data present the median fold changes $\mathrm{n}=100$.

The best discriminating cut-off values according to the ROC curve when comparing the SCI patients with control, for TP53INP2mRNA was2.005 as shown in Figure (4).

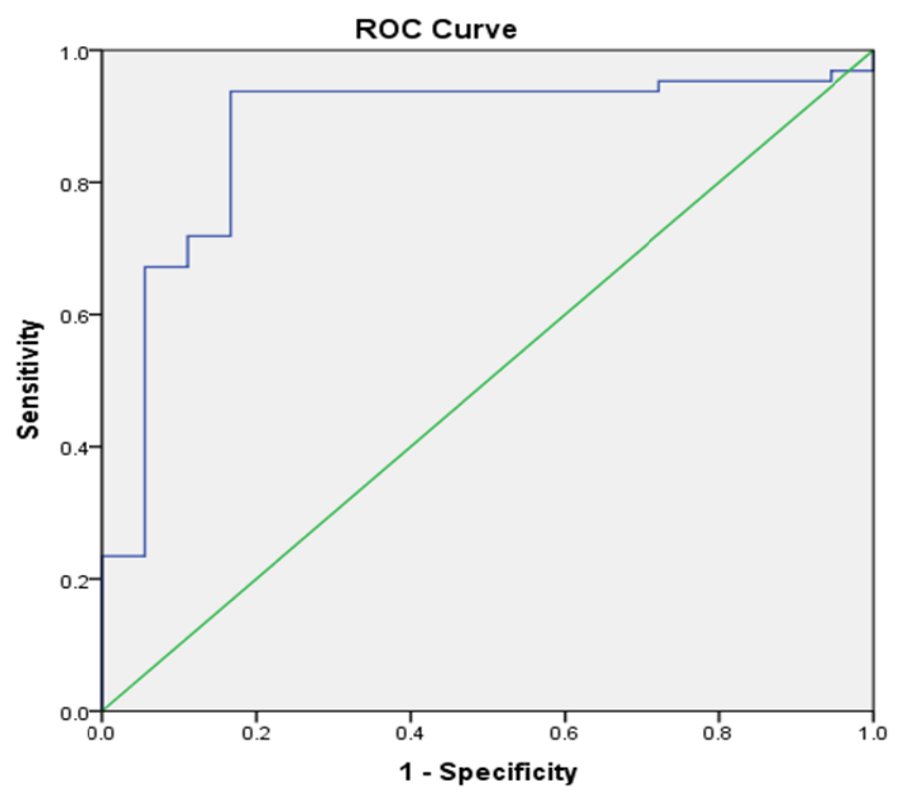

Figure 4: ROC for prediction of SCI using fold change of TP53INP2. 
The positivity rates of TP53INP2 $m R N A$ was $(91.3 \%)$ in the Acute SCI group. While among the Chronic SCI patients, the positivity rates of TP53INP2 mRNA was
(92.7\%). However, among normal control, the positivity rates of TP53INP2mRNA was $(19.4 \%)(\mathrm{p}<0.01)$, as shown in Table (3).

Table 3: Positivity rate of TP53INP2 among the different study groups

\begin{tabular}{|c|c|c|c|c|c|}
\hline & $\begin{array}{c}\text { Acute (SCI) } \\
\mathrm{N}(\%)\end{array}$ & $\begin{array}{c}\text { Chronic (SCI) } \\
\mathrm{N}(\%)\end{array}$ & $\begin{array}{c}\text { Healthy control } \\
\mathrm{N}(\%)\end{array}$ & $\chi^{2(a)}$ & $P$ \\
\hline $\begin{array}{c}\text { TP53INP2 mRNA: } \\
\text { Positive (66) } \\
\text { Negative(34) }\end{array}$ & $\begin{array}{c}21(91.3 \%) \\
2(8.7 \%)\end{array}$ & $\begin{array}{c}38(92.7 \%) \\
3(7.3 \%)\end{array}$ & $\begin{array}{c}7(19.4 \%) \\
29(80.6 \%)\end{array}$ & 54.343 & $.000 * *$ \\
\hline
\end{tabular}

${ }^{\mathrm{a} C h i-~ s q u a r e ~ t e s t, ~ S C I: ~ S p i n a l ~ C o r d ~ I n j u r y, ~ m R N A: ~ m e s s e n g e r ~ r i b o n u c l e i c ~ a c i d, ~ P: ~ P ~ v a l u e, ~}{ }^{* *} \mathrm{p}<$

0.01: Highly Significant, $* p<0.05$ : Significant, $p>0.05$ : Non Significant $n=100$.

As regards the sensitivity, specificity, positive predictive value, negative predictive value and accuracy of serum TP53INP2
mRNA was $(93.75 \%, 83.33 \%, 90.9 \%, 88.2 \%$ and $90 \%$ ) respectively, as shown in Table (4).

Table 4: Performance characteristics of the investigated serum TP53INP2 mRNA among different groups of the study.

\begin{tabular}{|c|c|c|c|c|c|}
\hline $\begin{array}{c}\text { RQ for serum TP53INP2 gene } \\
\text { Expression }\end{array}$ & Sensitivity & Specificity & PPV & NPV & Accuracy \\
\hline Positive If $\geq 2.005$ & $93.75 \%$ & $83.33 \%$ & $90.9 \%$ & $88.2 \%$ & $90 \%$ \\
\hline
\end{tabular}

mRNA: messenger ribonucleic acid, PPV: Positive predictive values, NPV: negative predictive values.

The comparison between RQ values of serum TP53INP2 mRNA and the different groups ( $\mathrm{P}>0.05)$ except for diabetes, affected clinicopathological factors revealed no significant difference within the diseased area of spinal cord,motor power and Manual Muscle Test (MMT) as shown in table(5).

Table 5: Relation between TP53INP2 mRNA RQ, positivity rate and different clinicopathological factors of the diseased groups:

\begin{tabular}{|c|c|c|c|c|c|c|}
\hline $\begin{array}{c}\text { Clinicopathological } \\
\text { factors }\end{array}$ & Median & Mean Rank & Statistics & $\begin{array}{c}\mathrm{N} \text { of cases } / 60 \geq \\
2.005(\%) \\
\end{array}$ & $\mathrm{P}$ & $\chi^{2(c)}$ \\
\hline $\begin{array}{l}\text { Mean age: } \\
\geq 44 \text { years } \\
<44 \text { years } \\
\end{array}$ & $\begin{array}{l}45.56 \\
22.70 \\
\end{array}$ & $\begin{array}{l}35.51 \\
28.37 \\
\end{array}$ & $\begin{array}{c}\mathrm{P}=0.13 \mathrm{NS} \\
\mathrm{U}^{(\mathrm{a})}=388\end{array}$ & $\begin{array}{l}35(58.3 \%) \\
25(41.7 \%)\end{array}$ & $\begin{array}{c}.744 \\
\text { NS }\end{array}$ & 0.107 \\
\hline \begin{tabular}{|l|} 
Sex: \\
Male \\
Female \\
\end{tabular} & $\begin{array}{l}26.93 \\
56.52 \\
\end{array}$ & $\begin{array}{l}31.09 \\
36.72 \\
\end{array}$ & $\begin{array}{l}\mathrm{P}=.29 \mathrm{NS} \\
\mathrm{U}^{(\mathrm{a})}=316\end{array}$ & $\begin{array}{l}44(73.3 \%) \\
16(26.7 \%) \\
\end{array}$ & $\begin{array}{l}.233 \\
\mathrm{NS}\end{array}$ & 1.42 \\
\hline $\begin{array}{l}\text { Smoking: } \\
\text { Smoker } \\
\text { Non-smoker } \\
\end{array}$ & $\begin{array}{l}44.32 \\
23.58 \\
\end{array}$ & $\begin{array}{l}34.89 \\
31.16 \\
\end{array}$ & $\begin{array}{l}\mathrm{P}=.441 \mathrm{NS} \\
\mathrm{U}^{(\mathrm{a})}=416\end{array}$ & $\begin{array}{l}22(36.7 \%) \\
38(63.3 \%) \\
\end{array}$ & $\begin{array}{l}.638 \\
\mathrm{NS}\end{array}$ & 0.222 \\
\hline $\begin{array}{l}\text { Hypertension: } \\
\text { Positive } \\
\text { Negative } \\
\end{array}$ & $\begin{array}{l}22.29 \\
37.61 \\
\end{array}$ & $\begin{array}{l}31.02 \\
33.27 \\
\end{array}$ & $\begin{array}{c}\mathrm{P}=.646 \mathrm{NS} \\
\mathrm{U}^{(\mathrm{a})}=429\end{array}$ & $\begin{array}{l}20(33.3 \%) \\
40(66.7 \%) \\
\end{array}$ & $\begin{array}{l}.497 \\
\mathrm{NS} \\
\end{array}$ & 0.462 \\
\hline $\begin{array}{l}\text { Diabetes: } \\
\text { Positive } \\
\text { Negative } \\
\end{array}$ & $\begin{array}{l}15.45 \\
54.56 \\
\end{array}$ & $\begin{array}{l}24.50 \\
36.14 \\
\end{array}$ & $\begin{array}{l}\mathrm{P}=.020 \mathrm{~S} \\
\mathrm{U}^{(\mathrm{a})}=280\end{array}$ & $\begin{array}{l}18(30.0 \%) \\
42(70.0 \%)\end{array}$ & $\begin{array}{l}.403 \\
\mathrm{NS} \\
\end{array}$ & .698 \\
\hline \begin{tabular}{|c} 
ASIA classification: \\
A \\
B \\
C \\
D \\
\end{tabular} & $\begin{array}{l}18.00 \\
26.93 \\
73.53 \\
53.81 \\
\end{array}$ & $\begin{array}{l}27.80 \\
30.63 \\
39.13 \\
35.62 \\
\end{array}$ & $\begin{array}{l}\mathrm{P}=.279 \mathrm{NS} \\
\chi^{2(\mathrm{~b})}=5.07\end{array}$ & $\begin{array}{c}21(35.0 \%) \\
15(25.0 \%) \\
4(6.7 \%) \\
16(26.7 \%) \\
\end{array}$ & $\begin{array}{l}.942 \\
\mathrm{NS}\end{array}$ & .772 \\
\hline
\end{tabular}


Sara Mohammed Mohammed Salah, et al.,

\begin{tabular}{|c|c|c|c|c|c|c|}
\hline $\mathrm{E}$ & 151.05 & 47.13 & & $4(6.7 \%)$ & & \\
\hline $\begin{array}{l}\text { Area of spinal cord } \\
\text { affected } \\
\text { One area } \\
\text { Two areas } \\
\text { Junctional area }\end{array}$ & $\begin{array}{c}45.5 \\
4.5 \\
8.6\end{array}$ & $\begin{array}{l}37.03 \\
18.67 \\
26.83\end{array}$ & $\begin{array}{c}\mathrm{P}=.0 .51 \mathrm{NS} \\
\chi^{2(\mathrm{~b})}=6.04\end{array}$ & $\begin{array}{c}38(63.3 \%) \\
2(3.3 \%) \\
20(33.3 \%)\end{array}$ & $\begin{array}{c}.017 \\
\text { S }\end{array}$ & 8.1 \\
\hline $\begin{array}{l}\text { Motor power } \\
\text { Paraplegic } \\
\text { Quadriplegic } \\
\text { Paraparetic } \\
\text { Quadriparetic } \\
\text { Monoparetic } \\
\text { intact MP } \\
\end{array}$ & $\begin{array}{c}22.7 \\
50.0 \\
38.2 \\
106.8 \\
60.0 \\
12.0 \\
\end{array}$ & $\begin{array}{l}32.83 \\
30.67 \\
35.94 \\
46.00 \\
31.00 \\
17.63 \\
\end{array}$ & $\begin{array}{l}\mathrm{P}=.57 \mathrm{NS} \\
\chi^{2(\mathrm{~b})}=3.8\end{array}$ & $\begin{array}{c}26(43.3 \%) \\
11(18.3 \%) \\
18(30 \%) \\
1(1.7 \%) \\
2(3.3 \%) \\
2(3.3 \%) \\
\end{array}$ & $\begin{array}{c}.011 \\
\mathrm{~S}\end{array}$ & 14.85 \\
\hline \begin{tabular}{|l|} 
Grading(MMT) \\
G0 \\
G1 \\
G2 \\
G3 \\
G4 \\
G5
\end{tabular} & $\begin{array}{c}23.5 \\
18.0 \\
167.5 \\
22.8 \\
76.2 \\
12.0 \\
\end{array}$ & $\begin{array}{l}32.17 \\
33.17 \\
51.00 \\
30.19 \\
39.00 \\
17.63 \\
\end{array}$ & $\begin{array}{l}\mathrm{P}=.34 \mathrm{NS} \\
\chi^{2(\mathrm{~b})}=5.6\end{array}$ & $\begin{array}{c}37(61.7 \%) \\
3(5 \%) \\
2(3.3 \%) \\
8(13.3 \%) \\
8(13.3 \%) \\
2(3.3 \%) \\
\end{array}$ & $\begin{array}{c}.012 \\
\mathrm{~S}\end{array}$ & 14.5 \\
\hline
\end{tabular}

a: Mann-Whitney test $\mathrm{b}$ :Kruskal-Wallis Test $\mathrm{c}$ : Chi- Square test. S; significant $(\mathrm{P} \leq 0.05)$, NS; Not significant $(\mathrm{P}>0.05)$, ASIA: American Spinal cord Injury Association, MMT: Manual Muscle Test and mRNA: messenger ribonucleic acid.

\section{DISCUSSION:}

This study was conducted on 100 Egyptian individuals, 23 acute spinal cord injury patients, 41 chronic spinal cord injury patients and 36 healthy control volunteers. At first we used the Bioinformatics analysis to retrieve mRNA specific to SCI and related to autophagy, then it was followed by validation of the expression of this mRNA in clinical sera samples.

Spinal cord injury (SCI) and the lifelong disabilities associated with it are of a major concern to the society worldwide ${ }^{(13)}$. Therefore, in order to provide optimized benefits to current therapies, it is necessary to identify the expression of novel, highly sensitive and specific biomarkers in SCI.

We identified the level of expression ofTP53INP2 mRNA which was strongly detected in the serum of SCI patients. Raising the susceptibility of using this mRNA as a circulating biomarkers for SCI prognosis and potential use of them as therapeutic targets.
As part of the autophagy, the protein encoded by tumor protein p53 inducible nuclear protein 2 (TP53INP2) gene has the key role in promoting autophagy and is essential for proper autophagosome formation and processing. In addition, the encoded protein can enhance rDNA transcription by helping in the assembly of the POLR1/RNA polymerase I preinitiation complex. Also this protein serves as a transcriptional activator for some genes ${ }^{(14)}$.

Kanno et al. (2009) ${ }^{(15)}$ first demonstrated that autophagy participates the pathogenesis in hemisection injury models. The mechanism underlying autophagyinduced cell death in injury is that excessive autophagy may cause programmed cell death $^{(16)}$.

The results of this study revealed that serum TP53INP2 mRNA was significantly up regulated in SCI patients when compared to normal healthy control individuals $(\mathrm{P}<$ $0.01)$. Previous reports done on tissue and cell lines also indicated that TP53INP2 displays a unique bifunctional role as a modulator of autophagy and gene transcription $^{(\mathbf{1 7})}$. Moreover $\mathrm{Hu}{ }^{\left({ }^{(18)}\right.}$ reveal the 
association of TP53INP2-related basal autophagy with cell growth and malignant progression of human liposarcoma, which helps re-evaluate targeting autophagy for cancer therapy, and suggest that TP53INP2 expression might be used as a prognostic marker to predict human liposarcoma malignancies $^{(\mathbf{1 8})}$.

The limitation of this study is that it was carried in a two centers in Egypt with a relatively small limited sample size, so, we recommend further large multicentric studies and more in vitro functional studies to determine the deep underlying molecular mechanism beyond the role of the chosen gene in SCI.

\section{Conclusion}

In the light of this study, we demonstrated the expression of TP53INP2 mRNA in SCI patients that may be a promising therapeutic target of SCI.

\section{REFERENCES}

1. Burstein HJ, Lacchetti C, Anderson H, Buchholz TA, Davidson NE, Gelmon KE, Giordano SH, Hudis CA, Solky AJ, Stearns V, Winer EP. Adjuvant endocrine therapy for women with hormone receptor-positive breast cancer: American Society of Clinical Oncology clinical practice guideline update on ovarian suppression. Journal of Clinical Oncology. 2016 Feb 16;34(14):1689-701.

2. Rowland JW, Hawryluk GWJ, Kwon B, FehlingsMG. Current status of acute spinal cord injury pathophysiology and emerging therapies: promise on the horizon. Neurosurg Focus (2008) 25:E2. doi: 10.3171/FOC.2008.25.11.E2

3. Stein DM, Sheth KN. Management of acute spinal cord injury. Contin Lifelong Learn Neurol. (2015) 21:159-87. doi: 10.1212/01.CON.0000461091.09736.0c

4. Badhiwala JH, Wilson JR, Kwon BK, Casha S, Fehlings MG. A review of clinical trials in spinal cord injury including biomarkers. Journal of neurotrauma. 2018;35(16):1906-17.

5. Tigchelaar, S., Gupta, R., Shannon, C. P., Streijger, F., Sinha, S., Flibotte, S., ...\& Charest-Morin, R. (2019). MicroRNA biomarkers in cerebrospinal fluid and serum reflect injury severity in human acute traumatic spinal cord injury. Journal of neurotrauma, (ja)540-545.

6. Pös, O., Biró, O., Szemes, T., \& Nagy, B. (2018). Circulating cell-free nucleic acids: characteristics and applications. European Journal of Human Genetics, 1,600-603.

7. Pehlivan, S. (2012). Circulating Cell-Free Nucleic Acids as Potential Biomarkers for Noninvasive Diagnosis of Diseases in the Future. BiochemPhysiol, 1, e109.) (circulating-cell-free-nucleic-acids-aspotential-biomarkers-for-noninvasivediagnosis-of-diseases-in-the-future-21689652.1000e109)

8. Jonas S, Izaurralde E. Towards a molecular understanding of microRNA-mediated gene silencing. Nat Rev Genet 2015;16:421-33. doi:10.1038/nrg3965

9. Deniz E, Erman B. Long noncoding RNA (lincRNA), a new paradigm in gene expression control. FunctIntegr Genomics 2016. doi:10.1007/s10142-016-0524-x

10. Li, Z., Chen, T., Cao, Y., Jiang, X., Lin, H., Zhang, J., \& Chen, Z. (2019). Pros and Cons: Autophagy in Acute Spinal Cord Injury. Neuroscience Bulletin, 1-5.

11. Xu, Y., Wan, W., Shou, X., Huang, R., You, Z., Shou, Y., ...\& Liu, W. (2016). TP53INP2/DOR, a mediator of cell autophagy, promotes rDNA transcription via facilitating the assembly of the POLR1/RNA polymerase I preinitiation complex at rDNA promoters. Autophagy, 12(7), 1118-1128.

12. Livak KJ, Schmittgen TD. Analysis of relative gene expression data using realtime quantitative PCR and the 2(-delta deltaC(T)) method. Methods 2001;25:4028.

13. Kramer, M. M., Acker, A., \&Ohana, N. (2018). Penetrating Spinal Cord Injury. 


\section{Sara Mohammed Mohammed Salah, et al.,}

In Essentials of Spinal Cord Injury Medicine. IntechOpen,304-308.

14. Xu, Y., Wan, W., Shou, X., Huang, R., You, Z., Shou, Y., ...\& Liu, W. (2016). TP53INP2/DOR, a mediator of cell autophagy, promotes rDNA transcription via facilitating the assembly of the POLR1/RNA polymerase I preinitiation complex at rDNA promoters. Autophagy, 12(7), 1118-1128.

15. Kanno, H., Ozawa, H., Sekiguchi, A, et al. (2009): Spinal cord injury induces upregulation of Beclin 1 and promotes autophagic cell death $[\mathrm{J}]$. Neurobiol Dis; 33(2):143-8.
16. Li, Z., Chen, T., Cao, Y., Jiang, X., Lin, H., Zhang, J. and Chen, Z. (2019): Pros and Cons: Autophagy in Acute Spinal Cord Injury. Neuroscience Bulletin; 1-5.

17. Sancho, A., Duran, J., García-España, A., Mauvezin, C., Alemu, E. A., Lamark, T., ...\&Chicote, J. U. (2012). DOR/Tp53inp2 and Tp53inp1 constitute a metazoan gene family encoding dual regulators of autophagy and transcription. PloS one, 7(3), e34034.

18. Hu, Y., Li, X., Xue, W., Pang, J., Meng, Y., Shen, Y., \& Xu, Q. (2017). TP53INP2related basal autophagy is involved in the growth and malignant progression in human liposarcoma cells. Biomedicine \& Pharmacotherapy, 88, 562-568.

$$
\begin{aligned}
& \text { التعبير عن الأحماض التووية الحره السابحه في حالات الاصابه في الحبل الشوكي }
\end{aligned}
$$

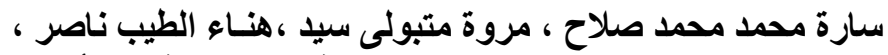

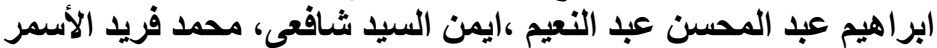

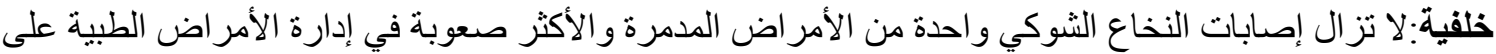

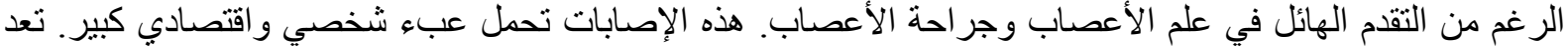

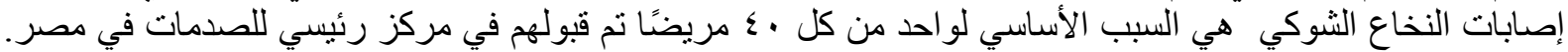

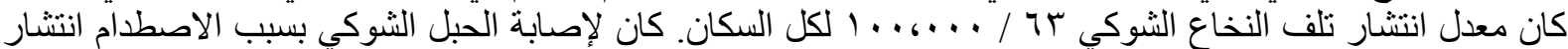

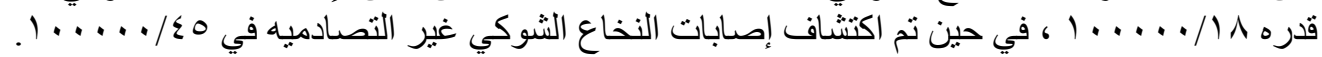

$$
\text { الهدف من البحث: نحن نهدف إلى استكثاف دور جينTP53INP2 السابح في التسبب في إصابة الحبل الثوكي. }
$$

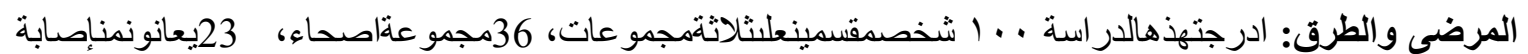

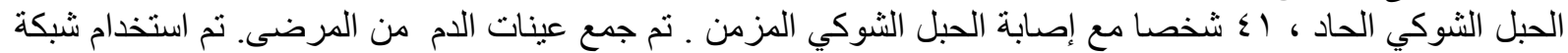

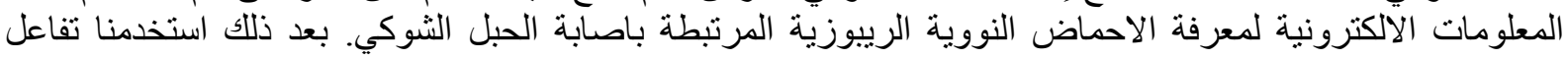

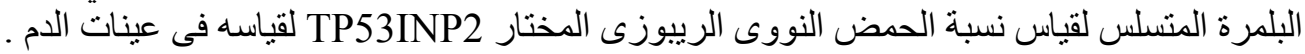

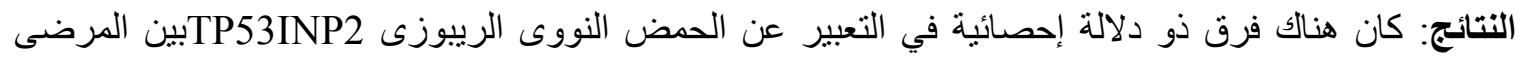

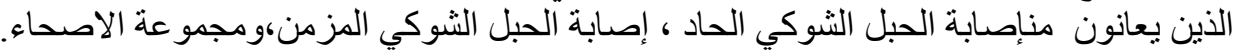

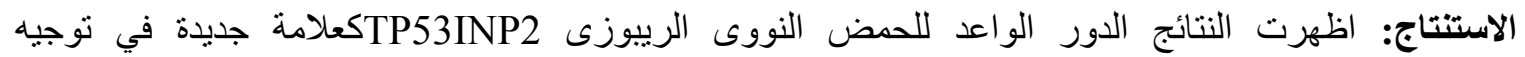
الاستر اتيجيات العلاجية للاصنابات النخاع الثوكي. 